\title{
PERSPECTIVE
}

\section{Sustainable intensification of agriculture in sub-Saharan Africa: first things first!}

\author{
Bernard VANLAUWE (ब ()$^{1}$, Achim DOBERMANN ${ }^{2}$ \\ 1 International Institute of Tropical Agriculture, Nairobi, 00100 Nairobi, Kenya \\ 2 International Fertilizer Association, 75116 Paris, France
}

We both belong to a generation of soils scientists and agronomists who have spent or are spending their career trying to develop and scale better soil and crop management solutions for smallholder farmers in the tropics. We have witnessed some successes in this, but also many disappointments. However, the work of the first author (BV) has primarily been in sub-Saharan Africa (SSA), while much of the work of the second author (AD) has been in Asia. We both believe that there is great urgency to accelerate crop production in Africa, the region with the greatest challenges for food and nutritional security and socioeconomic prosperity. We believe that what SSA needs most now is an agronomic revolution.

This paper presents our personal reflections on what should come first, knowing very well that the challenge is complex, requiring well-tailored, longer-term plans for numerous interventions driven by many different actors. Naturally, such plans for the sustainable development of agriculture differ widely and we are not able to cover all aspects of this here. Although SSA clearly has its own biophysical and socioeconomic characteristics, we believe that it can benefit greatly from experiences of other regions, including making sure that first things come first, thereby avoiding earlier mistakes.

\section{The African challenge is not so different}

Sub-Saharan Africa is facing challenges and opportunities that are not fundamentally different from what other world regions have experienced at different stages of their development. We know that there is a large food demand-supply gap that may even widen in the coming decades as a result of rapid population and income growth $^{[1]}$. We also know that although there are large crop yield gaps that must be reduced, this alone will not be sufficient to feed Africa. Consequently, similarly to what happened in other regions of the world, agricultural development in SSA must also include cropland expansion, increasing cropping intensity on existing land and expansion of irrigation ${ }^{[2]}$, but doing that in a socially and environmentally sustainable manner. It is also clear that there are massive nutrient gaps that must be overcome in $\mathrm{SSA}^{[3]}$.

Finally, as in other regions, SSA is also undergoing a structural transformation of its economy and farming, which is likely to accelerate in the coming years ${ }^{[4,5]}$. The key outcomes of this typically include: growing ruralurban market integration, a dramatic decline of the share of population working in agriculture, more aggregation of farms and/or services and value chains, increasing input use, higher labor productivity and a greater need for mechanization. Countries in SSA are at different stages of development and structural transformation, and there is also huge variation within countries in the use of inputs such as seed, fertilizers and other agrochemicals, machinery and irrigation ${ }^{[6]}$. The basic economic and social forces driving the structural transformation of farming in SSA will largely also drive the solutions that need to be found for sustainable

Received June 6, 2020

Correspondence: b.vanlauwe@cgiar.org

(C) The Author(s) 2020. Published by Higher Education Press. This is an open access article under the CC BY license (http://creativecommons.org/licenses/by/4.0) 
intensification (SI) of crop production, and they will differ somewhat among countries and agricultural sectors. Despite the complexity of this, we argue that focus must be pragmatic and on a few things that must come first.

\section{Sustainable intensification of agriculture}

No one with common sense will disagree with the need for farming systems in SSA - and in other regions of the world for that matter - to be sustainably intensified ${ }^{[7]}$. Although SI is generally ill-defined, most agricultural experts agree that it necessarily integrates increased crop productivity and profitability, sustenance of key ecosystem services regulated or affected by agricultural land and inputs, and stability of production against shocks and stresses such as climate change. This is, however, where the overall agreement usually stops since there are many views on system boundaries for SI, appropriate intervention scales, and specific technologies or solutions. In essence, $\mathrm{SI}$ in most of the academic literature denotes an ambition, but does not specify a priori how it should be attained ${ }^{[8]}$. We are most interested in what SI encompasses in practice in terms of cropping systems, agronomic principles and practices, genetic improvement, and enabling technologies and support systems. This alone leaves plenty of choices for how to move from the current situation to a desired form of SI, and it presents a problem in terms of identifying the right order of priorities.

How will SI ultimately look like in practice in SSA? What are profitable, low-risk crop rotations or cropping systems that can produce sufficient products for own consumption and the market? What is the minimum level of crop diversity that is required to retain productivity and other services? Does SI necessarily include agronomic measures that facilitate soil surface cover and increase nutrient recycling? How much of the $\mathrm{N}$ needed by the farming systems can biological $\mathrm{N}$ fixation supply? What about other nutrients and avoiding that those get depleted in soils? How does one manage crop health to avoid losses due to weeds, insects or diseases, while also having to meet high product quality standards? How can one sustainably mechanize smallholder farming in SSA? How can one capture and use more water for increasing cropping intensity and yields? These and many other questions are valid, but they often resolve to 10-20 concrete decisions farmers need to make when growing crops in a particular environment. These questions are not easy to answer and the answers may vary from place to place or year to year.

Investment in R\&D must therefore focus on generating answers that will guide the movement toward SI in a concrete manner, especially since there is limited agreement in the science and practitioner community on what valid answers would look like. For example, one of us (BV) was recently an advisor to a project in Madagascar on rice intensification. During a visit to a trial site evaluating the impact of various organic inputs for possible agroecological intensification, a positive control with mineral fertilizer was also included that clearly yielded best. The project proponents, however, did not pay any attention to those treatments since they were not part of the stated objectives of the project. However, in many areas of SSA where fallows have disappeared, or nearly so, and where yields are low and soils continuously degraded, answers to these questions are not an immediate priority as in many cases, and for most of the land. Although it can be argued that limited areas under smallholder farming systems are closer to what is called $\mathrm{SI}$, especially in the small plots nearing the farmhouse where a diverse range of crops is produced and most recycling of organic waste occurs ${ }^{[9]}$, the current production systems are distant from whatever SI could look like (Fig. 1). So whereas FAO promotes Save and Grow as an approach to SI for smallholder farming ${ }^{[11]}$, based on the assumption that soil can be saved and then used to grow crops productivity, we wonder whether it would be more appropriate for many smallholders in SSA to have had this strategy framed as first grow more crops and then save your soil.

In a sense, the immediate key question is not what is contained in SI but how does one move from current production systems toward SI, taking into account the constraints under which smallholders in SSA operate. It is important to note that medium- or large-scale commercial agriculture in SSA can be as successful as agriculture in the Northern Hemisphere and should be viewed as an important component of agrarian change and $\mathrm{SI}$ in $\mathrm{SSA}^{[4]}$. Also, these constraints are many, including high risk aversion, limited access to resources, presence of hunger months where food availability drops below food security needs, lack of income-generating opportunities, limited access to credit, uncertain land tenure, among others ${ }^{[7]}$. This is where things often go wrong. Many agricultural experts have a specific vision of what SI constitutes and then push their technology to smallholder farming communities, often supported by unsustainable incentives in cash and/or in kind. For example, one of us (BV) spent most of his early career on alley cropping systems in West Africa. Such systems are based on a number of hypotheses related to increased nutrient recoveries and use when trees or shrubs are intercropped with annual crops. On-station development of these systems resulted in a set of technologies that worked well for $\mathrm{N}$-demanding crops, leading the researchers to believe that these must be of utmost 


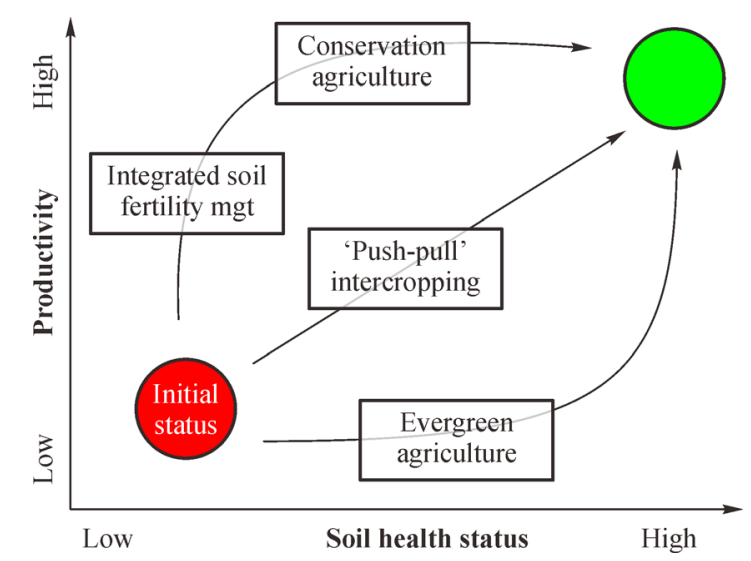

Fig. 1 Conceptual pathways from a current situation (degraded soil with low productivity) to a SI situation (healthy soil and high productivity) with various popular intensification paradigms included based on their estimated position along specific pathways ${ }^{[10]}$. Tailored or site-specific fertilizer recommendations are a key component of integrated soil fertility mgt (management). Alley cropping could be hosted under evergreen agriculture.

interest to farmers. When this technology was exposed to farming communities, it became rapidly clear that the key incentive for farmers - increased crop yields - took too long to materialize. In combination with a suit of other constraints this resulted in particularly low uptake rates. The history of research on soil fertility management in SSA is full of such examples; good ideas that were scientifically sound but had little potential for wider-scale adoption $^{[12]}$.

\section{Lesson 1: Smallholders need immediate returns on their investments}

If there is one key lesson we have learned over the years, it is that smallholders need immediate returns on their investments, mostly in terms of increased yields to achieve greater profit. One of us (AD) has always used a simple rule of thumb without clear scientific evidence: any new agronomic intervention (such as inputs, better practice, better decision and new technology) must lead to a recognizable yield increase and a profit increase of at least $50 \mathrm{USD} \cdot \mathrm{ha}^{-1}$ to be of interest to farmers. Without such immediate benefits, any alternative technology is doomed to fail. In that sense, the only viable route to SI in SSA is through the upper left route of Fig. 1. Alternative incentive schemes, such as payment for environmental services (PES), may provide extra benefits to farmers, but it is hard to imagine how an SI model for SSA could be successful on that basis alone.

\section{Lesson 2: Sustainable intensification cannot happen without the use of fertilizer}

A second lesson learned is that intensification cannot happen without the use of fertilizer, but SI requires that such input is used as efficiently as possible, both for environmental and for economic reasons.

The many 'white elephants' or failed, industrial projects erected all over SSA demonstrate that economic development in that region needs to be triggered by agricultural development, especially if often over $70 \%$ of the active population is engaged in agriculture. While noting that without growth in production, there can be no agricultural development, experience from practically all other world regions demonstrates that growth in crop production is strongly driven by growth in fertilizer use, at least during the first decades of agricultural intensification. Why then does one often find experts, mostly from outside SSA, advocating for alternative ways to intensify crop production on the continent without this essential agro-input, often based on the argument that fertilizers are bad for the environment, or make farmers 'addicted' to products developed by large multinational companies, among other reasons. It is ironic that proponents of the anti-fertilizer community are often seen 
using laptops or drinking cola, also products from large multinational companies that could be said to create similar levels of 'addiction'.

In that context, we are strong proponents of integrated soil fertility management (ISFM), which focuses on the systematic co-deployment of fertilizer and other amendments and practices to maximize the use efficiency of external inputs ${ }^{[13]}$ (Fig. 2). ISFM tailors nutrient management to site-specific conditions in terms of what the crop requires, what the soil can supply, and what needs to be supplied by fertilizer and any organic inputs that may be available. It aims to build and sustain soil health, and it can also be climate-smart, because the use of organic inputs and other soil amendments can result in better soil moisture dynamics and increase soil carbon stocks $^{[14]}$.

\section{Lesson 3: Investment in fertilizer needs to be combined with other agronomic improvements}

A third lesson learned is that investment in fertilizer needs to be combined with a minimal number of other agronomic improvements and investments aiming at maximizing the profitability and resource efficiency of this input.

Whether it is cheap or expensive, fertilizer will always come at a cost and the returns on investing in this commodity need to be large and stable over time. Fortunately, leaders and governments in SSA are actively supporting the increased use of fertilizer in the region, partly triggered by the 2006 Abuja Fertilizer Summit, where it was declared that, "Given the strategic importance of fertilizer in achieving the African Green Revolution to end hunger, the African Union Member States resolve to increase the level of use of fertilizer from the current average of $8 \mathrm{~kg} \cdot \mathrm{ha}^{-1}$ to an average of at least $50 \mathrm{~kg} \cdot \mathrm{ha}^{-1}$ by 2015 ." We note that the average rate is approaching $20 \mathrm{~kg} \cdot \mathrm{ha}^{-1}$ in 2020 (excluding South Africa) (Fig. 3) and reached the Abuja target in 4 countries in 2017 (Kenya, Mali, Zambia, and South-Africa) while Ethiopia, Malawi, Botswana, and Zimbabwe reached average values between 30 and $50 \mathrm{~kg} \cdot \mathrm{ha}^{-1}$ in 2017 . This is significant progress but also implies that most African soils continue to be mined of nutrients.

However, countries with strong government support for fertilizer use have reached rates close to the Abuja commitment, including Ethiopia, Mali and Zambia. These are necessary but not sufficient developments. Although subsidies for fertilizer are getting smarter ${ }^{[15]}$, thereby ensuring that the subsidies are entering the pocket of the farmer instead of intermediaries, such subsidy schemes are best limited in time because of their substantial cost. Increased fertilizer use thus needs to be combined with other investments that aim at

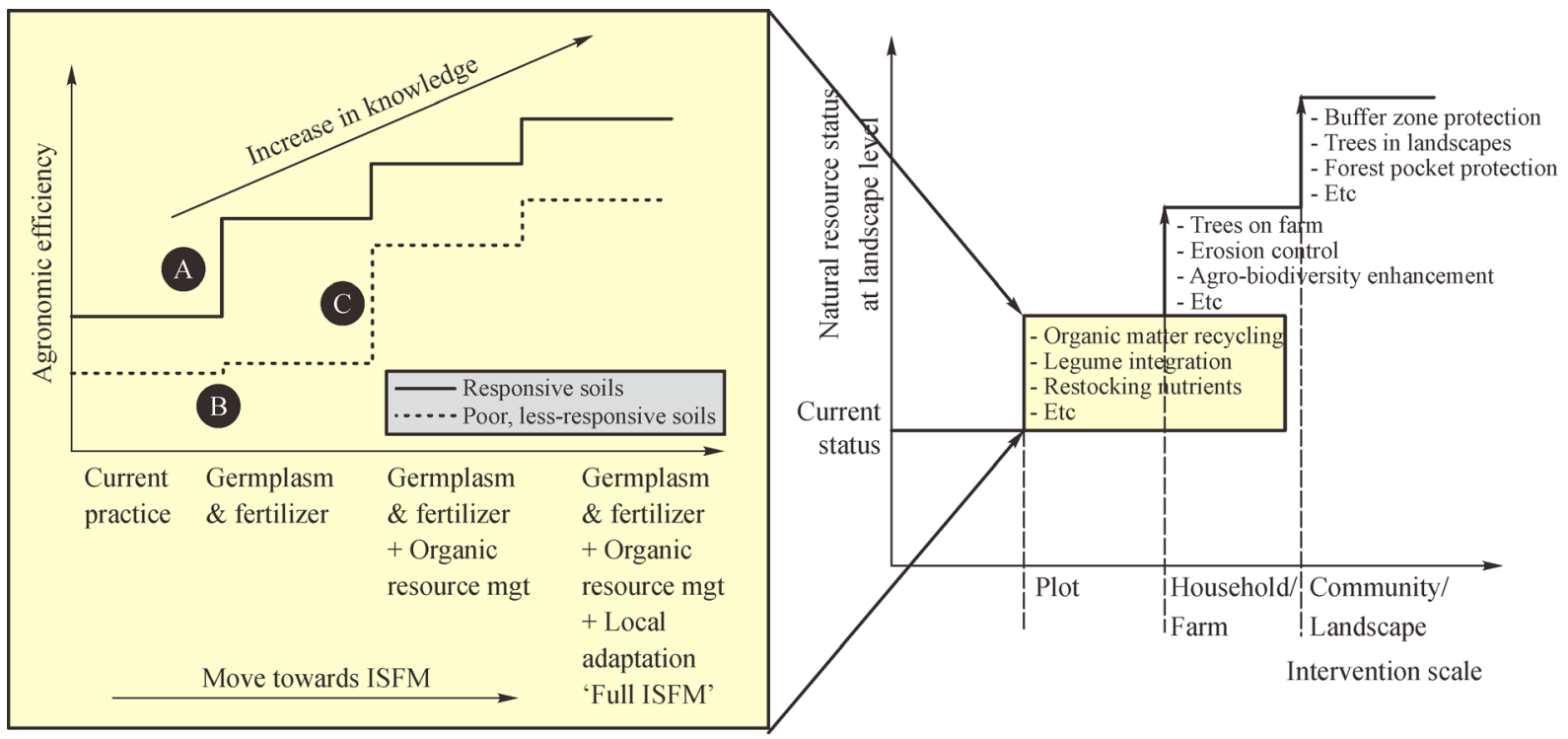

Fig. 2 Conceptual depiction of integrated soil fertility management (ISFM), aiming at maximizing the agronomic efficiency of applied inputs through the proper deployment of improved cultivars, fertilizer and organic inputs, adapted to local conditions (adapted from Vanlauwe et al. ${ }^{[13]}$ ) (left part) and conceptual progression toward natural resource integrity, starting with improved productivity on a single farm (right part). 


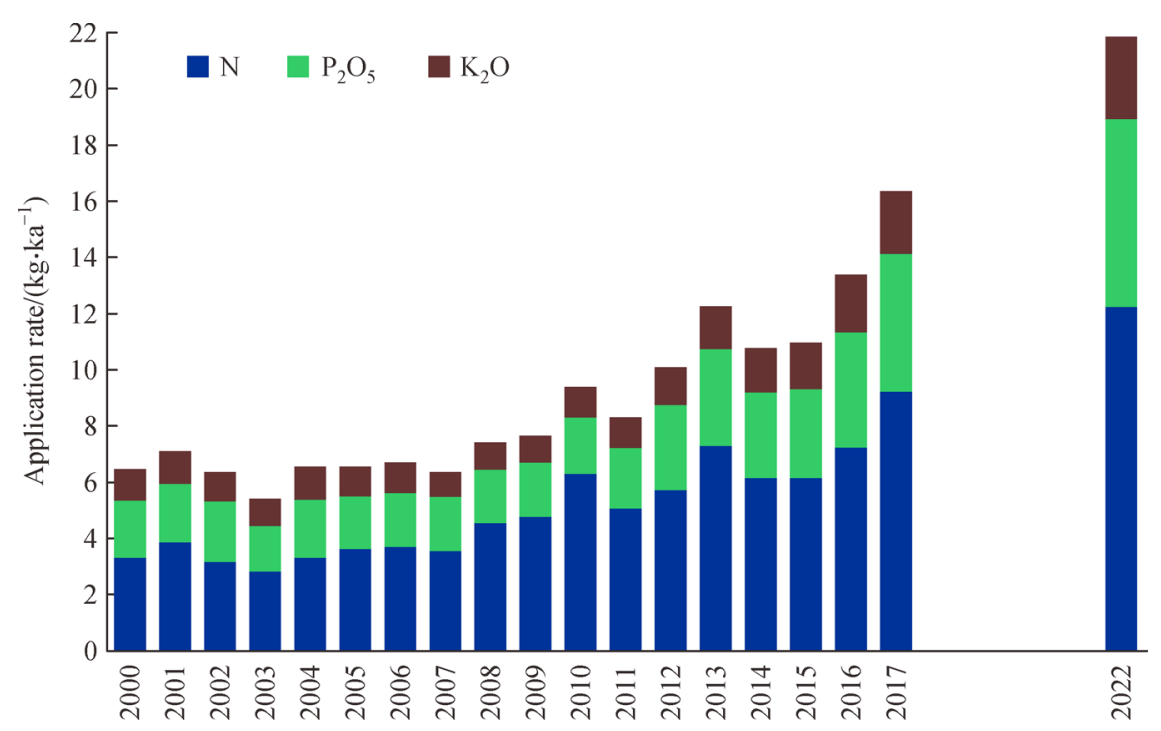

Fig. 3 Average rates of fertilizer-nutrient application to cropland in Africa for Sub-Saharan Africa, excluding South Africa, noting that 2022 figures are projected figures. Source: Patrick Heffer, International Fertilizer Association (IFA) 2019; calculation using IFA fertilizer consumption and fertilizer use by crops statistics and FAO cropland statistics.

maximizing the value generated by the use of fertilizer. This includes improvements in rural infrastructure, access to profitable output markets, investments in irrigation for high value crops, functional agro-input supply chains for seed, fertilizer, soil amendments such as lime, agricultural tools and pesticides. Probably some of the advocates of the 'no-fertilizer' community recognize that making fertilizer available to farmers requires a minimum level of commercialization of their farms, beyond the 'small-is-beautiful' image. Over the past 30 years, we have never met a smallholder anywhere in SSA or in the whole world who does not want to earn more from his or her land and labor to materialize some of their aspirations.

\section{Lesson 4: Investments in technologies that target environmental services should follow profitable increases in crop yield and not vice versa}

A fourth lesson learned is that the sustainability of investments in technologies that target environmental services above crop yields should follow profitable increases in crop yield and not the reverse. Although often well-intended, applying the reverse logic will not result in sustainability nor intensification of smallholder farming systems.

Once smallholders start benefiting from increased yields, production and income, then investments in other aspects of their farming system can happen, for example, to introduce better crop rotations and new crops with potentially higher market value, grow more trees on their farms, enhance the soil organic matter pool or prevent soil erosion (Fig. 2). Increased yields result in increased availability of organic resources, mainly in the form of crop residues that can be left in the field, for example as mulch, or recycled as manure after being fed to livestock. Conservation agriculture, for example, cannot function under low fertility conditions since the amount of mulch available within farm would not be sufficient to provide a minimal amount of soil cover ${ }^{[16]}$. In a sense, ISFM is a set of precursor technologies that can generate the conditions to apply conservation agriculture or similar practices (Fig. 1).

We see many attempts in SSA to promote technologies or practices that do not yield immediate benefits but may provide one-off or time-bound payments for other purpose, for example, PES or food-for-work schemes. These may be tempting for farming communities, but what happens when such incentive schemes cease to exist?

Ultimately, SI requires not only sufficiently high crop yields or high nutrient use efficiency, but also the maintenance of other ecosystem services. Some of these ecosystem services operate at scales beyond a single plot or farm (e.g., aquifer replenishment, water pollution control and biodiversity) and require interventions at a landscape scale, thus necessarily engaging rural and urban communities rather than 
individual farm households. Therefore, it is argued that if good practices are not implemented by all farmers in a farming landscape, then SI will not be achieved. Of course, it is well known that farming households within a large region as well as within a single area are highly diverse in terms of production objectives or access to resources $^{[17]}$ and the fact that a significant proportion of such households is trapped in poverty is also being recognized, even within the donor community ${ }^{[18]}$. Such households are potentially going to drop out of agricultural activities, as alternative livelihood opportunities arise, but it is unclear when these will become available in sufficient numbers to absorb the large number of poverty-trapped smallholder families. Until this happens, SI will only be realized if those households also have sufficient means to live a fulfilling life (e.g., based on living income indicators) and stop further degradation of the natural resources they are managing. The cost for this likely supersedes the cost of fertilizer subsidy schemes or other good agronomic practices.

\section{Conclusion: Sustainable intensification as a vision for agriculture rather than a short-term solution}

Principles of SI can form the basis for well-defined national agricultural development plans and associated policies and investment strategies that learn from the best. African countries should join forces in working establish these principles, and share positive experiences, but besides a grand ambition they should not lose sight of the most pressing needs. There are many exciting new opportunities, such as digital technologies or rapid advances in microbiology and crop genetic improvement, but a true agronomic revolution is needed, supported by big data, remote sensing, new sensors and analytics, and digital tools. This is needed to first to jump to a new level of crop production performance, based on the key ingredients that simply cannot be neglected: looking after soil, cropping systems and agronomic practices, seed, fertilizer, water and crop health. Suitable small-scale mechanization and capturing more water will be vital to enable good agronomy and higher land and labor productivity. The projected huge increase of livestock production in SSA ${ }^{[1]}$ will present both new challenges and opportunities, requiring a good integration of crop and livestock farming and avoiding mistakes that were made in many other regions of the world.

In the short-term, however, SI in SSA is more of an ambition, a vision for smallholder agriculture in SSA, than something that is realizable. However, for now the top priority is to ensure that crop yields are increasing with maximal resource use efficiences of production factors and with high returns on investment for a large proportion of smallholder farmers by bringing better agronomy to scale. First things first!

Compliance with ethics guidelines Bernard Vanlauwe and Achim Dobermann declare that they have no conflicts of interest or financial conflicts to disclose.

This article does not contain any studies with human or animal subjects performed by any of the authors.

\section{References}

1. Food and Agriculture Organization of the United Nations (FAO). The future of food and agriculture — alternative pathways to 2050. Rome: FAO, 2018

2. van Ittersum M K, van Bussel L G J, Wolf J, Grassini P, van Wart J, Guilpart N, Claessens L, de Groot H, Wiebe K, Mason-D’Croz D, Yang H, Boogaard H, van Oort P A, van Loon M P, Saito K, Adimo O, Adjei-Nsiah S, Agali A, Bala A, Chikowo R, Kaizzi K, Kouressy M, Makoi J H, Ouattara K, Tesfaye K, Cassman K G. Can sub-Saharan Africa feed itself? Proceedings of the National Academy of Sciences of the United States of America, 2016, 113(52): 14964-14969

3. Ten Berge H F M, Hijbeek R, van Loon M, Rurinda J, Tesfaye K, Zingore S, Craufurd P, van Heerwaarden J, Brentrup F, Schröder J J, Boogaard H L, de Groot H LE, van Ittersum M K. Maize crop nutrient input requirements for food security in sub-Saharan Africa. Global Food Security, 2019, 23: 9-21

4. Barrett C B, Christian P, Shimeles A. The processes of structural transformation of African agriculture and rural spaces. World Development, 2018, 105: 283-285

5. Senbet L W, Simbanegavi W. Agriculture and structural transformation in Africa: an overview. Journal of African Economies, 2017, 26(suppl_1): i3-i10

6. Sheahan M, Barrett C B. Ten striking facts about agricultural input use in Sub-Saharan Africa. Food Policy, 2017, 67: 12-25

7. The Montpellier Panel. Sustainable intensification: a new paradigm for African agriculture. London: Imperial College, 2013

8. Garnett T, Appleby M C, Balmford A, Bateman I J, Benton T G, Bloomer P, Burlingame B, Dawkins M, Dolan L, Fraser D, Herrero M, Hoffmann I, Smith P, Thornton P K, Toulmin C, Vermeulen S J, Godfray H C J. Sustainable intensification in agriculture: premises and policies. Science, 2013, 341(6141): 33-34 
9. Tittonell P, Vanlauwe B, Leffelaar P A, Shepherd K D, Giller K E. Exploring diversity in soil fertility management of smallholder farms in western Kenya: II. Within-farm variability in resource allocation, nutrient flows and soil fertility status. Agriculture, Ecosystems \& Environment, 2005, 110(3): 166-184

10. Vanlauwe B, Coyne D, Gockowski J, Hauser S, Huising J, Masso C, Nziguheba G, Schut M, van Asten P. Sustainable intensification and the African smallholder farmer. Current Opinion in Environmental Sustainability, 2014, 8: 15-22

11. Food and Agriculture Organization of the United Nations (FAO). Save and Grow: a policymaker's guide to the sustainable intensification of smallholder crop production. Rome: FAO, 2011

12. Vanlauwe B, AbdelGadir A H, Adewopo J, Adjei-Nsiah S, Ampadu-Boakye T, Asare R, Baijukya F, Baars E, Bekunda M, Coyne D, Dianda M, Dontsop-Nguezet P M, Ebanyat P, Hauser S, Huising J, Jalloh A, Jassogne L, Kamai N, Kamara A, Kanampiu F, Kehbila A, Kintche K, Kreye C, Larbi A, Masso C, Matungulu P, Mohammed I, Nabahungu L, Nielsen F, Nziguheba G, Pypers P, Roobroeck D, Schut M, Taulya G, Thuita M, Uzokwe V N E, van Asten P, Wairegi L, Yemefack M, Mutsaers H J W. Looking back and moving forward: 50 years of soil and soil fertility management research in sub-Saharan Africa. International Journal of Agricultural Sustainability, 2017, 15(6): 613-631

13. Vanlauwe B, Bationo A, Chianu J, Giller K E, Merckx R, Mokwunye U, Ohiokpehai O, Pypers P, Tabo R, Shepherd K D, Smaling E M A, Woomer P L, Sanginga N. Integrated soil fertility management: operational definition and consequences for implementation and dissemination. Outlook on Agriculture, 2010, 39(1): 17-24

14. Roobroeck D, van Asten P, Jama B, et al.. Integrated Soil Fertility Management: contributions of framework and practices to climate-smart agriculture. Climate-Smart Agriculture Practice Brief. Copenhagen, Denmark: Agriculture \& Food Security, 2015

15. Jayne T S, Mason N M, Burke W J, Ariga J. Review: taking stock of Africa's second-generation agricultural input subsidy programs. Food Policy, 2018, 75: 1-14

16. Vanlauwe B, Wendt J, Giller K E, Corbeels M, Gerard B, Nolte C. A fourth principle is required to define conservation agriculture in sub-Saharan Africa: the appropriate use of fertilizer to enhance crop productivity. Field Crops Research, 2014, 155: 10-13

17. Tittonell P, Vanlauwe B, Leffelaar P A, Rowe E C, Giller K E. Exploring diversity in soil fertility management of smallholder farms in western Kenya. I. Heterogeneity at region and farm scale. Agriculture, Ecosystems \& Environment, 2005, 110(3-4): 149-165

18. Department for International Development (DFID). DFID's Conceptual Framework on Agriculture. London: DFID, 2015 